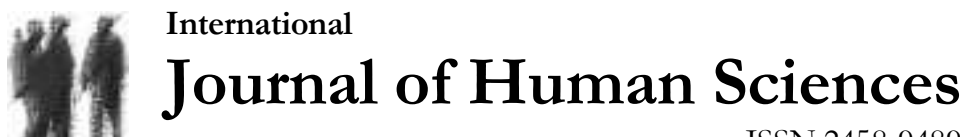 \\ ISSN:2458-9489
}

Volume 16 Issue 4 Year: 2019

\section{Approaches to the certain meanings of garments' ripped outlooks}

\author{
Arzu Evecen ${ }^{1}$
}

\section{Giysilerdeki yırtık görünümlerin kimi anlamları üzerine yaklaşımlar}

"Yoksul çocuklar zengin görünmek istiyor, Zengin çocuklar da yoksul"

(Davis, 1997:74)

\begin{abstract}
When we consider garments as communication tools, we realize that they reach from an idea or a thought to a representative form of existence. Garments that contain a specific notice or an expression in themselves, are re-shaped within a design phenomenon through various stylistic applications. Even though many styles of garments evoke traditional and usual styles, they don't refrain from telling other things by re-emerging at different times and extensions. It is possible to express about garments that our motive to create a common language within a social structure fuelling with cultural values, is one of the most basic purposes that serve to non-verbal communication. Periodic references belong to different styles, different shapes that are created on the material surfaces and any kind of formal images that serve to appearance, constitute iconic or symbolic indication styles that serve to garments' taking on a meaning process. Although the message wanted to be given by a garment varies from an era to era and from condition to condition, it becomes an integral part of a meaningful whole, as long as it is understandable from the viewpoint of the society. This is a descriptive research that is about analyzing every kind of alterations of garments' ripped outlooks of traditional eras including postmodern era, and also this research is done in order to reveal
\end{abstract}

\section{Özet}

Giysileri bir iletişim aracı olarak düşündüğümüzde, bir fikir ya da düşünceden temsili bir varoluş biçimine uzandığını görürüz. Belirli bir bildiri ya da bir söylemi içinde barındıran giysiler, çeşitli biçimsel uygulamalarla tasarım olgusu içerisinde yeniden şekil alır. Bazı giysi biçimleri geleneksel anlamda alışılagelmiş stillere çağrışım yapsa da farklı zaman ve uzamlarda yeniden ortaya çıkarak başka şeyleri söylemekten geri kalmazlar. Giysilere ilişkin, kültürel değerlerden beslenerek toplumsal yapı içerisinde ortak bir dil yaratma güdümünün, sözsüz iletişime hizmet eden en temel amaçlarından biri olduğunu da ifade etmek mümkündür. Farklı stillere ait dönemsel göndermeler, malzeme yüzeylerinde oluşturulan farklı biçimler ile görünümüne hizmet eden her türlü şekilsel görüntüler, giysilerin anlamlandırılma sürecine hizmet eden görüntüsel ya da sembolik gösterge biçimlerini oluşturmaktadırlar. Giysi ile verilmek istenen mesaj, her dönemde ve koşulda değişkenlik gösterse de toplumsal açıdan aynı oranda anlaşılabilir olduğu sürece anlamlı bir bütünün parçası haline gelmektedir. $\mathrm{Bu}$ araştırma, giysilerdeki yırtık görünümlerin geleneksel dönemlerden postmodern dönemi de kapsayan sürece kadar geçirdiği her türden değişimleri incelenme konusunda, giysilerin yüzeylerinde bilinçli ya da bilinçsiz oluşturulan

${ }^{1}$ Asst. Prof., Çankırı Karatekin University, Faculty of Fine Arts, Fashion And Textile Design, arzuterli@gmail.com. 
Evecen, A. (2019). Giysilerdeki yırtık görünümlerin kimi anlamları üzerine yaklaşımlar. Journal of Human Sciences, 16(4), 916-930. doi:10.14687/jhs.v16i4.5804

which idea did these consciously or ve bütünseli ayıran "yırtık" görünümlerin siyasi, unconsciously created "ripped" outlooks on sosyal, kültürel vb. değerlerle örtüştürülerek garments that distinguish wholistic coinciding hangi düşüncenin temeline yaslandığını ve with political, social and cultural values, based hangi görünümlerle bunu sağladığını ortaya on. Moreover, this research is done to learn by çıkarmak amacına ulaşılmak üzere yapilmış the way of which outlooks did this fact is provided. In the research, stylistic and thematic specifications of "ripped" outlooks are made, garments' explanation styles and ripped outlooks' questionings related to cultural memory are tried to be explained with sufficient and equivalent examples during the process. It is concluded that ripped outlooks, which are pictographic representation devices of various cultural values of garments from past to present, undergo lexical changes depending on time and extension, moreover, these lexical changes are shaped associating with a lot of social, cultural, economic and/or psychologic communal characteristics.

Keywords: Garment fashion, ripped surface, garment language, deconstructivism, poor fashions.

betimsel bir araştırmadır. Araştırmada günümüzde bir tasarım unsuru halini alan giysi yüzeylerindeki “yırtık" görünümlerin süreç içerisinde biçimsel ve izleksel tanımlamaları yapılmış, bu görünümlerle giysilerin anlamlandırılma biçimi ortaya konulmuş ve yırtık görünümlerin kültürel belleğe ilişkin sorgulamaları yeterince karş1lk bulunan örneklerle açıklanmaya çalışılmıştır. Geçmişten bugüne giysilerde çeşitli kültürel değerlerin görüntüsel bir temsil aracı olarak ifade bulan yırtık görünümlerin zaman ve uzama göre türlü anlamsal değişimlere uğradığı, bu anlamsal değişimlerin sosyal, kültürel, ekonomik ve/ya psikolojik birçok toplumsal niteliklerle ilişkili olarak biçimlendiği sonucuna varılmıştır.

Anahtar Kelimeler: Giysi modası; yırtık yüzey, giysi dili; dekonstüriktivizm; yoksul modası.

(Extended English summary is at the end of this document)

\section{Giriş}

Birtakım düşünürler giysinin bir metin olduğu görüşünü dile getirirler. Giysinin bir metin olarak ele alınması esasen onu eğretilemeli bir kullanıma sokar ki bu durum kodların veya mesajların okuyucu tarafından doğru anlamlandırılması şeklinde ifadelendirilebilir. Verilmek istenen temel mesaj giyside açık ya da örtük biçimde çeşitli şekillerde (renk, şekil, kumaş, yüzey tasarımı, stil v.b.) göstergeleşirken oluşturulan anlamlı dizge, alıcının zihin yetisinden kültürel belleğine değişim gösterebilmektedir.

Giysilerin, inanç, görüş, statü, zenginlik gibi kimliği ifade etme aracı olarak kullanıldığında toplumsal daha sonra da kişisel özellikleri aç1klayabilecek sözel bir metin haline dönüşmesi mümkündür. Böylece giysilere yüklenen anlamlar, temel ve sözel bir kültür öğesi olma işlevine de hizmet etmektedir (Koç ve Koca, 2011, 71).

Oğuz vd. (akt. Fidan, 2011:96) "giysi, iletişimsel açıdan bir metindir” sözünden yola çıkarak, son derece elverişli olduğu kısa ve kalıcı mesajların kodlanmasıyla doldurulan giysi metninin, iletişim sürecine katılanların, birbirlerinin farkına vardıkları andan süreç sonlanıncaya kadar etkisini sürdürdüğ̈̈” görüşünü vurgularlar.

Öyle ki, moda olgusu içerisinde sürekli kendini tekrar eden giysi biçimleri, yeniden ortaya çıktıklarında sunulmak istenen mesajın kodlarıyla donanırlar. Bu kodlar okuyucuya belirli bir bildirim verme amac1 güder. Yani giysi üzerinden kodlarla bir mesaj iletilmek hedeflenir. Fakat verilmek istenen temel düşünce ile bunu anlamlandırma biçimi her zaman istenilen düzeyde buluşamaz. Bazı kodlar açık biçimde göstergeleştirilmişken bazıları ise kapalı yani sembolik bir mesaj güderler. Bu kodları istenilen nitelikte çözümleyebilmek için ortak bir dilden hareket etmek gerekmektedir. 
"Giyimin ilettiği mesaj, sessiz sözsüz bir dilin parçası olup görsel ya da hareketsiz sembollerin kullanılması" ile oluşur. Sosyolog Goffman, bu tip sembolleri, "statü belirleyici, kişileri birbirinden ayırt edici, diğer insanların onlara nasıl davranmaları gerektiğinin mesajını gösteren işaret ya da işaret taşıyıcıları" olarak tanımlamaktadır (Ercivan ve Meydan, 2007: 77).

Buraya kadar aktarılan tüm bu söylemler ve açıklamalar, konumuz bağlamında şekillenen yırtık görünümlerin giysilerdeki anlamlandırma sürecini destekleyen açıklamalar niteliğindedir. Giysilerin anlamlandırılma sürecine dair bilimsel yaklaşımlarla ve bunları destekleyen örneklerle okura bilinçli bir bakış açısı kazandırmak ve görülen biçimlerin sadece giyside estetik vb. bir beğeni yaratımından öte bir anlam biçimi yaratmasının farkındalığını kazandırmak, çalışmanın önemini ortaya koymaktadır. Çalışmanın kapsamı, geleneksel toplumlardan modern toplumlara uzanan yırtık görünümlerin biçimsel özelliklerini, anlamsal dönüşüm ve değişim şekillerini, zamana ve uzama yönelik türlü ifade biçimlerini vb., belirlemeye ve giysilere hangi türden bir dil yetisi kazandırdığını çözümlemeye yöneliktir.

Betimsel bir araştırma olan bu çalışmanın yöntemi nitel olup, veri toplamada doküman analizi tekniğinden yararlanılmıştır. Veriler, yerli ve yabancı kitap, dergi, tez gibi üniversite kütüphanelerinin arşivlerinden ve konu kapsamında internet kanalıyla ulaşılan bazı bilimsel ve görsel nitelikteki yayınların taranmasıyla elde edilmiştir. Birtakım kuramcıların bilimsel temelli yaklaşımlarından konu kapsamında yapılan doğrudan ve dolaylı alıntılar, çalışmanın kavramsal çerçevesi oluşturulmuştur.

Giysilerdeki yırtı görünümlerin farklı dönemlerde, farklı uygulamalarda, farklı anlamlar taşıdığını ortaya koymaya çalışmak bu araştırmanın varsayımı niteliğindedir. Araştırmada bulunan görseller, giysilerdeki yırtık biçimlerin temel anlamlarından uzaklaşarak ironik bir anlayışa büründüğü 16. yüzyıldan 21. yüzyıl modasındaki güncel tasarımlara uzanan dönemin en tanımlayıc1 Örnekleriyle sinırlı tutulmuştur.

\section{Tanım ve Kapsam}

Giysi temel bir gereksinim olmasının yanında mesaj aktarmaya yönelik özel bir söylem aracıdır. Bu durumda giysilerin görünümlerinde var olan çeşitli biçimlerle de anlam kazanabildiklerini ifade etmek mümkündür. Giysinin rengi ya da modeli geçmişe bir referans sağlayabilir. Yüzeyinde var olan süslemeler ya da tasarımı destekleyen herhangi bir biçimsel görünüm, giysiye gotik, romantik, maskülen vs bir stil kazandırabilir. Bu amaçla giysi tarihi boyunca giysi yüzeyinde oluşan veya oluşturulmuş her türden yırtık görünüm de tıpk1 diğer biçimler gibi birçok duruma gönderme yapabilir.

Davis (1997:16)'in de ifade ettiği biçimde, "sosyolojik olarak kıyafet ve moda ele alındığında, bireyler giysileri aracilı̆ıyla otobiyografi veya felsefeleri ile ilgili "bir şey"lere değinir, kolektif düzeyde seyirci de bu "bir şey"leri simge kabul eder ve bazı kategoriler içerisine sokar. Bu kategoriler statüleri ve hayat tarzlarını barındırabilmektedir".

Öyle ki giysi yüzeyindeki yırtk görünümleri, daha önce pek de düşünülmediği bir biçimde sosyal, kültürel, ekonomik, psikolojik ya da coğrafik birçok unsurla ilişkilendirmek mümkündür. Yırtık giysiler, sınıflı ya da geleneksel toplumlarda sözlük anlamına yakın bir söylemi örneklerken, gelişmiş kimi toplumlarda kendini var etme çabasını, kimilerinde lüks bir yoksulluğu, kimilerinde ise asi bir dışavurumu yansıtmaktadır.

Esasen yüzeylerde bir çeşit deformasyon görünümüne sahip olan "yırtık”, “ 1- yırtılmış durumda olan, 2- eskimiş, parçalanmıs, 3- yırtılma sonucu oluşmuş yer” (Püsküllüoğlu,1995:1651) olarak tanımlanmaktadır. Yırtık görünümler kumaş yüzeyinde yer alan dikey, yatay, verev kesikler biçiminde yer alabildiği gibi, deformasyon sonucu oluşan delikler ve/veya kumaşın atkı ve çözgü ipliklerinin kopması sonucu meydana gelen yüzey görünümüdür. Bilinçli veya bilinçsiz şekilde oluşan bu görünüm yüzeydeki bütünlük algısını bozarken, aynı zamanda gizil bir anlam algısını da beraberinde getirmektedir.

Geçmişe uzanıldığında gelenekli (bir bakıma sınıflı) toplum anlayışında giysi yüzeylerindeki yırtılmaların bir tür deformasyon ve eskimenin sonucu olduğunu ifade etmek olasıdır. Doğal bir reaksiyonla bu yüzeyde oluşan eskime ve deformasyonun, coğrafi özelliklere bağlı olarak doğal 
Evecen, A. (2019). Giysilerdeki yırtk görünümlerin kimi anlamları üzerine yaklaşımlar. Journal of Human Sciences, 16(4), 916-930. doi:10.14687/jhs.v16i4.5804

kaynaklı malzemelerle dokunan yüzeylerin kullanım sıklı̆gından ötürü dayanıksız olma durumuyla açıklanabilir. Bu durum yırtılmanın sosyolojik bakımdan eskime mantığına bürünmesinin doğal ve bilindik bir sonucudur.

Esasen bu görünüm geleneksel anlayışta bir bakıma sosyo ekonomik düzeyin de bir göstergesi sayılmaktadır. Tarıma dayalı toplumlarda kullanılan gündelik giysiler, işin niteliğine bağlı olarak kullanım sıklığından ötürü yıpranmışlık görüntüsüne bürünmekteydiler. Bunun sonucunda yırtık görünümler gösterişsiz, özensiz ve eskimiş biçimleri andırmaktaydı. Derin anlamında ise bir çeşit yoksunluk ve yoksulluğun bir işareti sayılmıştır.

\section{Yırtık Giysi Biçimlerine İlişkin Örneklemeler}

Geçmişte yırtık görünümlü giysilerin Diakov ve Kovalev (2014:54)'a göre "bütün haklardan yoksun ve hayatının hiçbir değeri olmayan" kölelere ithaf edildiğine dair bilgilerin, onların yamalı giysilerinde karşılık bulduğunu belirtmek mümkündür.

Çoğu kaynakta kölelerin genellikle eski, yamalı, ucuz kumaşlardan yapılan paçavra giysiler giydiklerinden ve bu giysilerin bir kısmının sahipleri tarafindan onlara verilen kullanılmış ve döküntü giysiler olduğundan (Taschek, 2009:45-48); bazı kölelerin (Roma'da) giysilerini ikinci el yamacılardan veya Centoii denilen kıyafet satıcılarından alındığından söz edilir. Cato'nun "yeni bir tunik veya pelerin verdiğinizde üzerlerine yama yapılması için eski olanlanı geri alın” (Olson, 2017) ifadesi, Roma'daki kölelerin yırtık giysilerinin yamanarak kullanılacağı fikrine atıf yapar niteliktedir.

Bu yırttk ve eski görünümü kapatma isteği ise "Patch" yani yamaların biçimsel kusurları örtmesi işlevini sağlamaktadır. Bunun yanında bir bakıma görünürün arkasındaki duygusal ilişkiyi de yansıtmaktadır. Baker ve Baker (1985:706), bir yamanın aslında bütüne ait bir parça olduğundan söz ederler. Aynı zamanda kaybın sembolü olarak duran bütünlügün üzerindeki izdir. Geriye kalan şey veya bir kalıntı olarak yama, parçalanmayı ve fakirleşmeyi sembolize edebilir; çoktan elden gitmiş olanin solgun zaferiyle tasvir edilebilir (Baker ve Baker, 1985:706).

Başka bir bakış açısıyla Kaşgarlı Mahmut tarafindan yazılan Divan-ü Lügat-it-Türk kitabında "Yamağ: Yama ve Yamağllğ: Yamalı (738)" ifadelerinin bulunması yamanın Türklerin de giyim kuşamında kullanılan bir teknik olduğunu gözler önüne sermektedir. Bu dönemde elbiselerin üzerinde bulunan yamalar, yırtık olarak kullanılan giysilerin toplumda ayıp karşılandığının ve bu sebepten yamalı olarak kullanılmasının uygunluğunu ifade ederken aynı zamanda ekonomik bir göstergenin de biçimsel bir sembolüydü (Bilal, 2018:541-542). Dolayısıyla giysilere yama yapmak yırtık görünümlerin giysileri daha fonksiyonel hale getirebilmenin yöntemlerinden biri olmuştur.

Giysi tarihinde yırtı biçimlerin bir başka görünümü "slashing" modasıyla ortaya çıkar ve ortaya çıkış biçimi esasen siyasi bir gönderme taşır. Bu akımın temeli tesadüfî olarak oluşan biçimlerin görsel temsillerine dayanmaktadır. Askeri üniformaların görünümlerinde oluşan yırtıklar ve sonucunda ortaya çıan stiller; "güç" olgusunun kodlanan göstergeleridir. Aristokrasi ve halk tarafından benimsenip taklit edilen bu stil, aynı zamanda güç ve iktidar (statü) duygularının temsiliyle özdeşleşmiştir.

Kelime anlamı olarak "yırtmaç; yırtmaç açmak; haşıllamak; yırtık" (Yılmaz, 2010:59), manalarına gelen "slash", "slashing" üst kumaşın kesilip alttaki materyalin gözükmesi işlemidir (Warne, 2000:20). Savaşta kilıç darbeleri vs oluşan asker giysilerindeki yırtıkları kapatmak veya yamamak olan slashing, Pendergast ve Pendergast (2003;452)'a göre on dördüncü yüzyllın sonları ile on altınc1 yüzyıllar arasında giysileri ayırt etmek ve güzelleştirmek için kullanılan dekoratif tekniklerden biridir. Bu teknik, yazara göre moda trendleri doğrultusunda dekoratif eklemeler yapmak üzere, kadınlar ve erkekler tarafından çok çeşitli kıyafetlerde (Fotoğraf 1) hatta ayakkabılarda bile kullanılmışır.

1479 yılndaki Grandson savaşında İsveçli askerlerin yırtılmış giysilerini ölenlerin giysilerinden çaldıkları parçalarla yamamaları "Slashing" modasının yaratım biçimi olarak ifadelendirilir (Kollektif, 2013: 78). Bir başka deyiş ise İsviçre ordusunun, düşman kamplarından yağmaladıkları renkli ipek kumaşları, soğuktan korunmak amacıyla yırtılan üniformalarının içine yerleştirmeleriyle ortaya çıktığıdır. Söylenilene göre bu doğaçlama davranış halkın geneli tarafından benimsenmiştir. Bu 
Evecen, A. (2019). Giysilerdeki yırtk görünümlerin kimi anlamları üzerine yaklaşımlar. Journal of Human Sciences, 16(4), 916-930. doi:10.14687/jhs.v16i4.5804

tarzın kökeni bu hikâye olsun ya da olmasın, şu bir gerçektir ki İsviçreli ve Almanyalı askerlerin üniformaları birden çok renkte kumaştan yapılmışlardır ve çeşitli kesiklerle ve yırtıklarla, dikişlerle ve katmanlarla dekore edilmişlerdir. Alman esintileri İtalya'da daha yumuşatılmış da olsa, aynı özellikler neredeyse her yerdeki erkek kiyafetlerinde bariz şekilde görünmektedir. Reade (1951) bu süslemelerin erkeklere ağır silahları kaldırırken ve savururken dikişleri fazla gerginleştirmemelerine olanak vermesi açısında kullanışlı bir değerinin de olduğunu ileri sürmüştür (Tortora ve Eubank, 2014:157).

Moda tarihinde giyen kişi için statüsel bir öneme sahip olan ve giysilerde süsleme amaciyla kullanılan bu kesikler, zamanla giyilebilir sanat içerisinde sanatsal bir obje niteliği kazanmıştır. Günümüzde tekstil sanatçıları tarafından dekoratif amaçlı teknikler olarak kullanılırken farklı renk kombineleri ve çeşitli kumaş katmanlarının verev, yatay, dikey kompozisyonlarda dikilip aralarının kesilmesiyle yeni biçimsel uygulamaları giyilebilir sanat formuna dönüştürmüştür (Özhan, 2018:338).

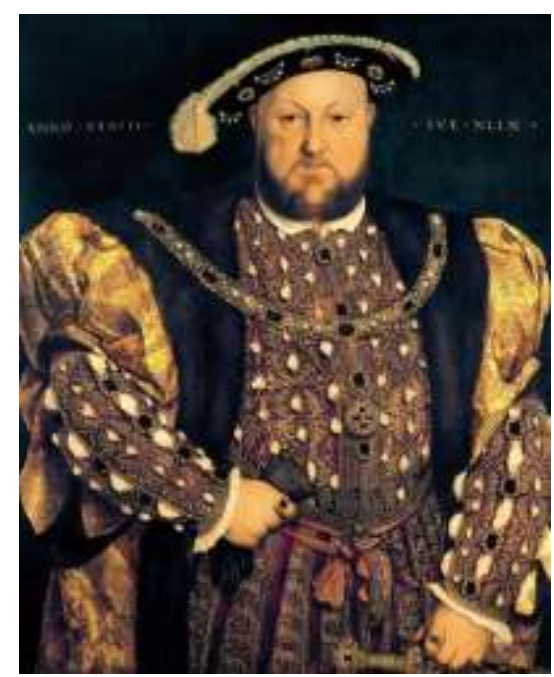

Fotoğraf 1: Slashing tarzı giysi stiline bir örnek, Henry VIII, King of England, 1540.

Yırtı̆̆ın sembolik bir giysi koduna bürünmüş bir diğer görünümünü alt kültür gruplarının düşünsel referanslarına gönderme yapan giysi biçimlerinde görmek mümkündür. $\mathrm{Bu}$ tarzlar, önceden var olan veya kendilerince var edilen stilleri, düşsel dünyalarının biçimsel formlarıla göstergeleştirerek bir ifade aracı niteliğine getirmişlerdir ki giysilerindeki yırtık görünümlerin de bu düşüncelere yaslandığını söylemek mümkündür.

Alt kültür terimi aktarıldığı biçimde, fonetik biçiminin düzanlamsal görüntüsünden uzak olarak, "egemen toplumsal düzenin kültürel normlarının ve ilişkilerinin dışında kendi normları ile yaşayan kendine özgü bir ahlakı, iletişim biçimini, barınma, giyinme, eğlenme, sanatsal faaliyet vb. alanlarda kültür adına farklı bir bütünlüğ̈̈ yeniden üreten bir topluluk, toplumsal ilişkiler sistemi” (akt. İşbilen, 2011:35) biçiminde tanımlanır.

“50’lerin beatnik'leri, 60’ların hippie'leri 70’lerin punk'ları (bunlar kendi içlerinde dazlaklar, hard rock'çlar, heavy metal'çiler gibi üslup bakımından farklılık gösteren alt gruplara ayrilmaktadır)" (Davis, 1995:201), gibi birçok altkültür gruplarının kendilerine özgü davranış kalıpları ve/ya popüler müzikten beslendikleri stilleri vardır. Kişisel görünümleri itibariyle kendilerini ifade etmede en temel gösterge hiç kuşkusuz giysi stilleri olmuştur.

Savaş sonrası dönemde işgücüne dâhil olmayan ergenler ve genç yetişkinlerden oluşan bazı sokak tarzları ve genç altkültür grupları için giyimin, yaşam biçimlerini daha kolay kontrol altına alabildikleri ve kendileri ile toplumsal çevrelerine yönelik tutumlarını daha kolay ifadelendirebildikleri bir araç olduğundan söz edilir. Bu gruplar önceden var edilmiş stilleri harmanlayarak çeşitli dış görünüşe ait biçimleri ve/ya kişisel deneyimlerini belirli bir grubun kimliği olabilecek biçimde bir araya toplamaktadırlar (akt. Crane, 2003:245). 
Evecen, A. (2019). Giysilerdeki yırtık görünümlerin kimi anlamları üzerine yaklaşımlar. Journal of Human Sciences, 16(4), 916-930. doi:10.14687/jhs.v16i4.5804

Çoğu kaynak punk, grunge, skinhead gibi grupların yırtık giysi giydiklerinden, bunun da bir tür "isyankar kostüm” olduğundan bahseder. Birçoğu, sıradan siyasal düzene ve toplumun kabul ettiği normlara karşı isyanlarını ve saldırganlıklarını giysilerindeki yırtık biçimlere refere etmiş gibi görünmektedirler. Dolayısıyla giysilerini, tepkisel tutumlarının bir yansıması biçiminde düşünmek mümkündür.

Gerçekten de, giysilerin argo ve kaba söylemlere karşlık gelebileceği fikrine koşut olarak, yırtık jeanler, önü iliklenmemiş gömlekler ve dağınık taranmamış saç biçimleri, giysilerdeki bayağı kelimeleri ifade edebilir (Bursaligil, 2009:8).

Yırtık giysiler denilince akla gelen ilk isim kuşkusuz Punk tarzıdır. Gündelik yaşam düzenine ve toplumsal birtakım normlara karşı isyankâr tutumlarını, beslendikleri müzik türleriyle dışa vururken aynı zamanda giysilerini de sözsüz bir iletişim aracı haline getirmişlerdir. Bazı alt kültür grupları da punk modasının yırtık giysilerini ödünç alarak kendi tarzlarına dâhil etmişlerdir (Fotoğraf 2).

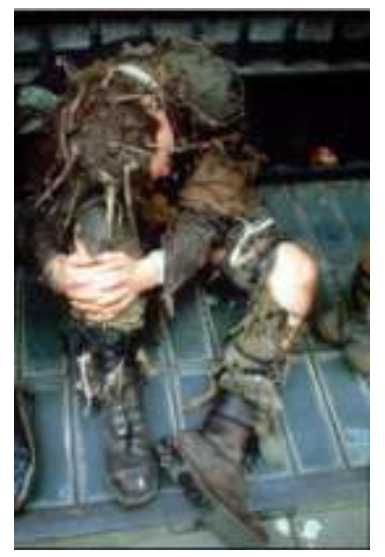

Fotoğraf 2: Punk tarzı giysi stiline bir örnek, REX USA / Nils Jorgensen Londra, 1983.

Punk için "giysileri, küfürlerinin dişavurumudur" (akt. İşbilen, 2011:202) söylemi, belki de onların protest kimliklerini ifade eden veya bu ifadeyi kuvvetlendiren görünümlerinin söze dökülmüş en iyi biçimidir.

Punk, sosyal bir başkaldırı olarak 1970'li yılların ortalarında Londra'da ortaya çıkmış bir akımdır (Ercivan ve Meydan: 2007:77). Punk, daha açık bir şekilde ideolojik bir hadise olarak anlaşılabilir. Hem burjuva kültürüyle hem de o kültüre özgü ürünler satan kapitalist sistemle mücadele etme amacı güden bir girişimdir. Punk, baskın ideolojilerle mücadele etmek ve sosyal düzende gücün dağılımına meydan okumak için modayı ve giyimi kullanmaktadır. Bunu yaparak, kıyafet konseptlerinin insanlar tarafindan alternatif konseptler düşünülerek oluşturulduğunu göstermek için, baskın sosyal sınıfların güzellik anlayışına dikkat çekmektedir (Barnard, 2002: 136-44).

Yabancılaşmalarını kıyafetleriyle dramatize etmek için olan çabaları yüzünden, rock müziğin sözde "pankçı" olarak anılan genç tutkunları, "dağınık, bol, yırtık kıyafetler” giymeye başlamışlardır. Kumaşlar deliklerle, "yırtık" larla ve çeşitli lekelerle biçim almıştır (Tortora ve Eubank, 2006:462).

Punk elbiseler, aslen 1960'larda New York'taki ve 1970'lerde Birleşik Krallık'taki yeraltı müzikallerinin üyeleriyle bağlantılılardı ve giyen kişi veya tasarımcısı tarafından deliklerle veya yırtıklarla kasten parçalanmış giysiler tercih etmişlerdir. Tuhaf biçimde sınıf içi bir ilişskide, zengin olan kendini fakirden "fakir gibi giyinerek" farklllaştırıyordu. Üzerinde delikler veya lekeler olan pahalı kotlar giyilerek onu giyen kişi ile o görünüşe bakan izleyici arasında anlam-takası, öncelikle o kotun fiyatını karşılayabilen ile ekonomik, sosyal ve psikolojik boyutları fark edebilenler arasında yönetiliyordu (Rhodes, 2010:11).

Bir başka alt kültür olan "skinhead"ler (dazlaklar) kendinden bir önceki dönemin gösterişli biçimlerine tepki olarak bol ve püsküllü yırtık elbiselerle birlikte dinledikleri müziğin kıyafetlerini yansıtan giysi seçimleri tercih etmişlerdir (Erol, 2013:75). 1980'lerin sonlarında doğan "New Age" adlı gezginlerin yırtık giysi giymelerinin diğer müzik akımları dışında başka bir sebebi vardır. İkinci 
Evecen, A. (2019). Giysilerdeki yırtk görünümlerin kimi anlamları üzerine yaklaşımlar. Journal of Human Sciences, 16(4), 916-930. doi:10.14687/jhs.v16i4.5804

el, ordu fazlası, el yapımı giysileri tercih edip kullanılmaz hale gelinceye kadar giymiş ve gezgin yaşamlarından dolayı kirli, tahrip olmuş ve yırtılmış giysi giymişlerdir (Crane, 2003:248).

Bununla birlikte Grunge akımında, ilk olarak Seattle'daki emekçiler tarafindan givilen kıyafetler (kareli gömlekler, tişörtler, mavi-günlük kotlar ve dağınık olanlar), müzisyenler ve sörfçüler tarafından benimsenmişlerdir. Bu "yoksulluk giyinişi”, biçimsiz baskılı elbiseleri, yırtılmıs kotları, soluk kot yelekleri ve kareli gömlekleri seven, grunge müzik fanları tarafindan benimsenmiştir (Tortora ve Eubank, 2006:507). Yine heavy metal grupları birçok giysinin yanında Punk müziğin yırtı giysilerini kullanmayı sürdürmüşler (Crane, 2003:244).

Bir bakıma "yırtlk" giysi biçiminin bir fikri yansıtma ve bu yolla yeni bir kişilik elde etme eyleminin diğer biçimini, alt kültür gruplarınca tercih edilen "yırtık kot" larda görmek mümkündür. Yırtık kot pantolon başlı başına direniş göstergeleri veya asi ruhun dışa vurum aracı olurken biçiminin bozulup yırtılması onun bu vurgulu anlamına destek sağlayarak daha baskın ve güçlü bir ifade diline dönmesini sağlamıştır.

İlk bakışta kot pantolonun, işçilik ve zorlayıcı fiziksel çalışma biçimiyle ilişkilendirildiğinde "demokrasi, bağımsızlık, eşitlik, özgürlük ve kardeşlik" gibi birtakım temel anlam örüntüleriyle özdeşleştirildiği fakat zamanla "sınıf ayrımları, elitizm ve züppelik" gibi anlamlara ifade edilir hale geldiğinden söz edilir. Kot pantolon, ortaya çıktı̆̆ dönemlerde ilk olarak Amerika'nın güneybatısındaki ressamlar ve sanatçıların "çalışmayan aykırılar" olarak tabir edildikleri gruplar tarafindan benimsenirken 1950’lerde "serseri" diye tabir edilen motorcular, 1960'larda "Yeni Sol" eylemcileri ve Hippie’ler, 1960 ortalarında ise "saygınlıktan yoksun ve düzen dışı" ifadeleriyle anılan motorcularla hippie’ler tarafindan giyilmiş, bu dönemden sonra ise tüm düşünsel ideolojileri aşıp popüler kültürün bir parçası haline gelmiştir (Davis, 1997: 85).

Esasen Amerikan giysisi olarak anılan kot pantolonların geçmiş ve günümüz arasında birçok anlam değişikliğiyle görünür kılındığı hakkında birçok söylem biçimi mevcuttur. Bununla ilişskili olarak Fiske (1999:15), temel anlamından uzak biçimde bazı muhtelif anlamları ve direniş jestlerini ifade eden görünümlere büründügünden söz ederken, onların renklerinin değiştirilerek, beyazlatılarak, ya da bilinçli olarak yırtılarak birtakım biçim bozukluklarına uğratıldığını ifadelendirir. Dolayısıyla yırtık kot giymek o dönemde Amerikan değerlerine karşı olma ve direniş biçiminin en temel örnekleri arasında sayılmaktadır.

Aynı zamanda yırtk kot, onu metasal anlamından farklı olarak kültürel bir kaynak olarak değerlendirmeyi olanaklı kılmaktadır. Yırtık kot giymek başta kullanıcının bilinçli seçim tercihinin olması ve bu giysiye yeni anlamlar kazandırması ile ilişkilidir. Bu ürünün üretimi ve seçimi Fiske (1999:22-27)'nin değimiyle 'bir metanın tabi bir alt kültüre ait kılınması ve metalaştırma sürecinin doğasında var olan gücün en azından bir kısmının tabi bir alt kültüre aktarılma" düşüncesine yaslanır. Ayrıca O’na göre yırtma eylemi “metalaştırmanın reddedilmesi ve kişinin meta sisteminin sağladığ1 kaynaklardan kendine ait bir kültür oluşturma hakkı"nı da görünür kılmaktadır.

Teknik açıdan yırtık kot görünümü, yüzeyinin kesilerek ve/ya aşındırlarak çeşitli mekanik işlemlerle atkı ve çözgü olarak adlandırılan yatay ve dikey yöndeki dokuma ipliklerinin kopmasıyla elde edilir. Son zamanlarda bu görünümü oldukça ilginç kıllan bir Japon markası olan "Zoo Jeans" lerdir.

"Zoo Jeans", "dünyada tehlikeli hayvanlar tarafindan tasarlanan tek kot markası" olarak ifadelendirilirler (Fotoğraf 3). Aslanlar, kaplanlar ve ayıların da dâhil olduğu hayvanlar, bu sürecin gerçek tasarımcıları olarak anılırlar. Şöyle ki, hayvanların en sevdiği oyuncaklarının etrafina kaplanan kotlar, Japonya, Hitachi de bulunan Kamine hayvanat bahçesindeki hayvan bölgelerinin içine atıllır (Holmes, 2014). Hayvanlar bu oyuncaklarla oynadıktan sonra kotlarda oluşan parçalanmaların ve yırtıkların, sanayi üretiminde ancak taklidinin yapılabileceği söylenmektedir. Yırtma ve parçalama işlemleri, kotları sadece klasik modellere benzetmek için değil aynı zamanda kotu bir araç olarak kullanmada yeni bir orijinallik yaratmak için, yeni tasarımların bir parçası olarak yapılmaktadır. Kotların yırtılma şekilleri, parçalanan ipliklerin nefes alacak boşluklar yaratmasına müsaade edecek kadar genişlerdir (Cochrane, 2014). 

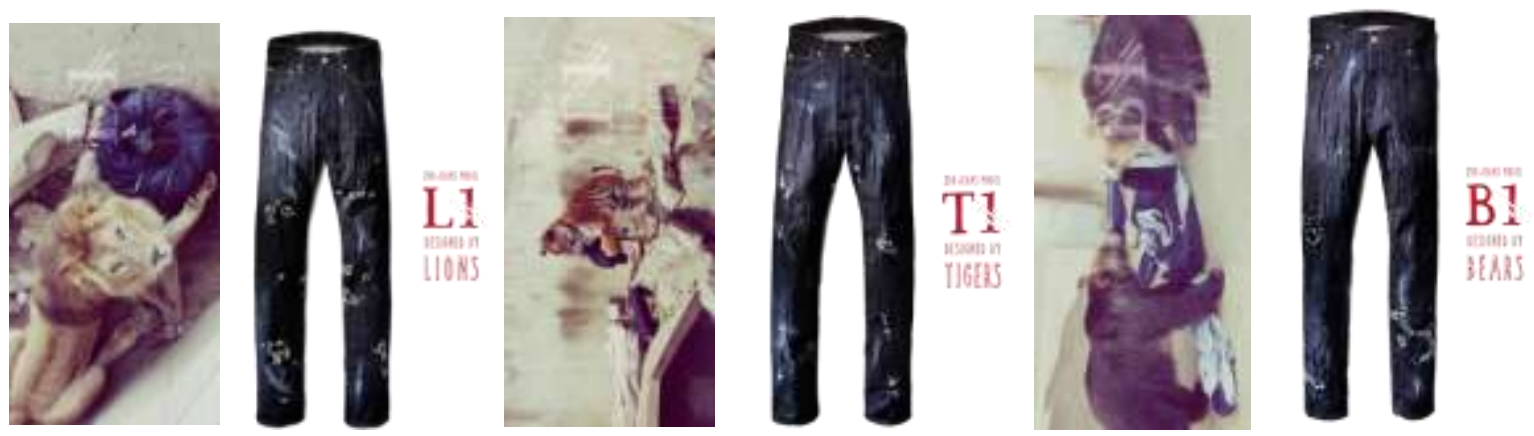

Fotoğraf 3: Zoo Jeans

Bu giysilerin yüksek fiyatlarla alıcı bulması, yırtığın meydana geliş biçimiyle doğrudan ilintili bir tutumdur. Sınırlı üretime sahip olan bu yırtk kotlar, konfordan ziyade kişilerin alım gücüne dair bir haz kazandırdığını söylemek mümkündür. Yırtık görünümle söz konusu eskime ve deformasyonun gelir seviyesi ile doğrudan bağlanttlı olduğu statüsel görünümlerin artık bir güç nesnesi ve algisı yaratarak yeniden biçimlendiği ve bu biçimlerin toplumda kişiyi var etmeye hizmet ettiği görünen bir gerçektir.

Bu söz konusu durum Davis (1997:79)'in toplumsal statü anlayışının muğlaklaşarak kodlanmış kimliklerin bulanıklaşması görüşünü destekleyen "zengin ile yoksulun tersyüz edilmesi ve geleneksel zenginlik alametlerinden feragat edilerek yüksek statü çağrışımları yaratma eğilimi” sözlerine yaslanabilir. Bu konuda yazar, Chanel'in "kisa siyah elbisesi" ni yoksul giysilerine bürünerek toplumsal üstünlük imasında bulunmanın bir örneği olarak görür. Bu giysi biçimi yalın bir sadeliği gözler önüne sererken bu yönüyle onu giyenlerin hizmetçilerine benzediği fikrini savlar ki bu da modanın statü simgelerini belirleme ve tersyüz etme anlayışıyla örtüşür.

Giysilerdeki yırtık görünümlerin bir başka biçimi, dekonstüriktivizm kavramının modaya aktarılma biçimiyle anlam kazanır. Birçok ifadeyle de anılan bu kavram 20. yüzyıl filozofu olarak bilinen Jacques Derrida’nın, kısaca bir metin okuma yöntemi olarak belirtmek mümkündür. Birçok alana uyarlandığı gibi moda alanında da kendini gösteren dekonstüriktivizm, giysilerin yırtık, sökük ve alışlagelmiş biçimlerinden uzak formlarda tasarlanması biçiminde karşımıza çıkar.

Dekonstrüksiyon, "bozmak (yıkmak), hem de yapmak (kurmak)" olgularının tanımsal terimlerini içeren destrüksiyon (destruktion) ve konstrüksiyon (konstruktion) ifadelerinin birleşiminden türetilmiş olmakla birlikte eşdeğerinde yapıçözüm, yapı bozum, yapısöküm” gibi birçok ifadeyle de anılmıstır Buradaki temel amacın yukarıda belirtildiği ifadeyle bağlantılı olarak bozmanın veya ortadan kaldırmanın aksine düşünce yapılarını parçalayarak tekrardan birleştirmek olduğu belirtilmektedir (Saydam, 2009:160-165).

Eşdeğer biçimde "Yapısöküm" kavramı, 1967'de Derrida tarafindan yayımlanan Ses ve Fenomen adlı eserde karşımıza çıkar ve esasen batı felsefesinin temel mantığına gönderme yapar (Rutli, 2016:52). Dekonstrüktivizm, felsefik bir kavram, bilimsel teori ve bir sanat eğilimi olarak da anlaşılmaktadır (Loshek, 2009:186). Tek bir disiplinle sınırlı kalmayan bu kavram, mutlak bir doğruyu reddeder ve okuyucuya farklı bakış açılarıla bu doğruları sorgulamayı önerir (Yanık, 2016:249).

En yalın biçimiyle yapısöküm (dekonstrüksiyon), "bize sunulan hazır değerlere karşı varolan yapının eleştirel sorgulanmasına dayanan bir yöntem" biçiminde ifade bulur (Ambrose ve Harris, 2012: 282). Tasarım, sanat ve mimarlikta yapılar ve formlar, parçalanmaya ve dekonstrüksiyona, yeniden yapım ve dönüşüm bağlamında yenilenmiş yapılanmaya tabidir. Giyside bunun anlamı görünmeyenin, ilginç ve önemli bir özellik olarak görünür hale getirilmesidir (Loshek, 2009:186). Aynı zamanda giysi üretim tekniğinin yapısını veya bitim işlemini parçalarına ayırarak keşfeden ve kıyafetlerde sadece gösterişli dış görünüşler yaratmak amacıyla var olan varsayımsal teknikleri ve bileşenleri ortaya çıkaran bir yaklaşım estetiğidir (Volpintesta, 2014:92). Giyside dekonstrüktif 
Evecen, A. (2019). Giysilerdeki yırtk görünümlerin kimi anlamları üzerine yaklaşımlar. Journal of Human Sciences, 16(4), 916-930. doi:10.14687/jhs.v16i4.5804

görünümler, geleneksel giysi anlayışından uzak tersi giysinin dışa dönmüş, uçları sökük, soluk veya yırtık yüzey görünümleriyle kendini gösterir (Ambrose ve Harris, 2012: 79).

Dekonstrüksiyon önceden kıyafet tasarımında neyin kabul edilebilir, neyin kabul edilemez olduğunu zorla kabul ettiren bir endüstrinin aksine, endüstriyi, tasarımciyı ve tüketiciyi özgür bırakmıştır. Örneğin, elbise kenarlarını artık dikkatlice katlanmak, astarlanmak ve dikiş olduğu gözle görülemez bir şekilde elle dikilmek zorunda değildir. Giysiler, içi dışına dönmüş, hatta kesilmiş ve işlem yapılmamış halde dahi bitirilebilirdi. Bu önceden düşünülmesi imkânsız olan bitim işlemi, hafif, ince, havadar biçimleri modaya getirdi (Volpintesta, 2014:96-97).

Dekonstrüktivistler, giysi oluşumunu, anlam arama ve sürekli olarak yeni anlam oluşturma olarak yorumlamaktadır. Geleneksel talimatlar ve diğer adetler ortadan kalkmakta ve vücut proporsiyonları ve güzellik kriterlerine ilişkin estetik alıskanlıklar sorgulanmaktadır (Loshek, 2009:186). Gösterişli biçimlerden uzak endüstrinin gizli olan sırlarını, giysilerin dış kısmında göz zevkini bozan bitim işlemleriyle açığa çıkaran ve onlarda güzellik bulan bu kavram, sert, parlak, ulaşılamaz çekicilikteki yıpranmış kumaşların, eşit olmayan uçların, bitirilmemiş ve tekrar sökülmüş bileşenlerin "çirkinleştirilmesi” veya parçaların genel bağlamlarından çıkarılması için giysi yapımının bütün yönlerini gözler önüne serer. Dekonstrüksiyonda, terzilerin sanatları ve el sanatları, bir şeylerin üzerindeki sır perdelerinin aralanması içindir ve bu halka bastırılmış duyguların ve imkanların dünyasını gösterir (Volpintesta, 2014:94).

Konumuz bağlamında ele alındığında yırtık biçimlerin dekonstrüktif görünümlerini, kumaş yüzeylerinde yapılan çeşitli manipülasyon uygulamaları kapsamında düşünmek mümkündür. Bununla ilişkili olarak Çileroğlu ve Balc1 (2018:18)', dekonstrüksiyon öğeleri ve giysi tasarım unsurlarını bir arada toplayarak oluşturdukları görsel analiz ölçek tanımlamalarında dekonstrüksiyon öğelerinin giysi tasarımlarına kazandırdığı biçimsel formların giyside ne türden bir ifadeye karşılık geleceğine yönelik yaptıkları sınıflandırmaları çalışmaya dayanak oluşturacak türden bilgileri içerir. $\mathrm{Bu}$ bağlamda giysideki yırtık görünümlerin dekonstrüksiyon öğelerinden "yapısızlaștırma" kavramının altında yer alan "kumaşın yapısını değiştirme" öğesinde karşılık bulabileceğini belirtmek mümkündür.

Burada kumaşın doğal ve sıradan görüntüsüne yeni dokular kazandırabilmek amacıyla bilinçli bir şekilde yüzeylerin değişime uğratıldığından söz edilir. Kumaş yüzeyinde ağartma, boyama, eskitme, keçeleşme, sökme v.b. işlemleri ile kumaşın fiziksel yapısı; kumaşın şeklini değiştiren ve biçim aldıran uygulamaların varlığı ile de manipülatif değişim uygulanmış olur (Çileroğlu ve Balcı, 2018: 19).

Dekonstüriktivizm bağlamında moda tasarımcıları tasarımlarına birçok yeni biçimler kazandırmış ve yırtı görünümleri tasarımlarının bir parçası olarak kullanmaktan geri kalmamışlardır.

Modada Japon tasarımc1 Rei Kawakubo (Commes des Garçons) ve Yohji Yamamoto, 1980’lerin başlarında tasarım algılarından yola çıkarak dekonstrüktivismin yolunu açmışır. 1990'larda ise Belçikalı tasarımcı Ann Demeulemeester ve Martin Margiela, kendilerini dekonstrüktivizmin başlıca temsilcileri olarak göstermiştir. Belçikalı Martin Margiela, dekonstrüktivizmin programa dayalı moda tasarımcısı olarak kabul edilmiştir (Loshek, 2009:187). Dekonstürksiyon, punk (serseri) ve sokak modasında, kıyafetlerin daha güzel bir tarz için yırtılarak ve sökülerek Vivienne Westwoood'ün ve Zandra Rhodes'in çalışmalarına ilham vermeleriyle başlamıştır (Volpintesta, 2014:96-97).

Martin Margiela ve Rei Kawabuko gibi tasarımcılar, 1980'lerin sonunda ve 1990'ların başında, dekonstrüktivizmin taktiklerini ve içyapılarını göstemeye başlayarak ve insanların gözlerine bitirilmemiş, yırtılmıs kıyafetlerin, geleneksel moda yapısı tekniklerinin yerini alan gelenekteki güzelliği fark ettirerek ve onları bu geleneğe alıştırarak modada devrim yaratmışlardır (Volpintesta, 2014:96-97).

Kawakubo, Japonca bir kelime olan "boro boro" yani eski püskü anlamina gelen estetik anlayışla tanınır. Bunun tasarımlardaki anlamı bazı kumaşlara ütüyle kalıcı kırışıklıklar ekler, bazılarını da yıpratarak önceden kullanılmış ve eskimiş görüntüsüne büründürür (Fogg, 2014:500). 
Tasarımcı Rei Kawakubo, Comme des Garçons markası için yaptığı çalışmada beden ve giysi arasındaki ilişkiyi yeniden tanımlayarak Batı modasının geleneklerine yeni bir estetik değer kazandırıp geleneklere büyük ölçüde meydan okumuştur. 1980’lerin başında ürettiği koleksiyonlanı Batı modasından estetik olarak oldukça farklı, yeni bir elbise konseptini tanıtmıştır. Bu elbise konsepti Harold Koda tarafindan "fakirliğin estetiği” olarak isimlendirilmiştir. Bu özel estetiğin nitelikleri olan giyside "fakir bir görüntü" yaratmak için konulmuş yırtıklar, delikler ve çukurlar yapılandırllmış bir anlayışı içermişlerdir (Krales, 2017).

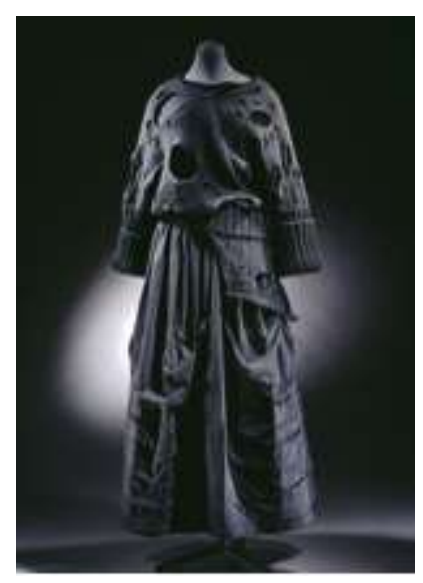

Fotoğraf 4: Rei Kawakubo/Comme des Garçons, 1982

Yukarıda siyah renkli kadın giysisi (Fotoğraf 4), delikli, el örgüsü bir süveterden ve pamuk jarseden yapılmış siyah renkli bir etekten oluşmaktadır. Bu giysi, siyah kazaklardaki deliklerin kazağın üzerine "bir böcek ordusu tarafindan yenmişçesine gelişigüzel konumlandırılmasının sayesinde "Dantel" koleksiyonunun bir parçası olmaktadır. Comme des Garçons'un tasarımları, özellikle "fakirliğin estetiğini”" tanıtarak "baskın sosyal değerlere veya sabit sanatsal geleneklere" karşı çıktğıından dolayı avant-garde (yenilikçi) olarak addedilebilir. Kawakubo kumaşları dügümleyerek, yırtarak ve keserek "sanatsal gelenekleri yeniden tanımlamışıı" ve Batı modasının gelenekseli, kusursuzu ve monotonlaştırılmışı tasarımlarında kullanmasını reddetmiştir. Kawakubo böylece üretimi, işlevi, rengi ve silüeti kullanarak Batı modasıyla mücadele etmiştir (akt. Krales, 2017).

Kawakubo'nun katmanlı ve yırtık kiyafetleri, Londralı tasarımcılar olan Vivienne Westwood ve Malcolm McClaren tarafindan kullanılan yırtılmış ve büyük bedenleştirilmiş "fakir görünüş" için olan bir genişlemedir (akt. Krales, 2017). Tam aksine, Westwood tarafindan oluşturulan bu görünüş, "ekonomik hüsran için önerilen bireysel-hicvin ve hiççi hazcıllğın” bir sonucu olarak İngiliz gençler tarafindan giyilmiştir (Krales, 2017).

Diğer tasarımcılar gibi Martin Margiela, çok küçük veya çok uzun olan kol gibi birbirine ait olmayan unsurları bir araya getirerek dekonstrüktivizmin parçalı unsurlarını görünür hale getirmiştir. Margiela, eski modayı geri dönüştürmektedir; dikişleri ve fermuarları tersine çevirmekte, döndürmektedir. Bu sayede terziliğin orijini ve yapaylığını ve modanın ruhunu veya ruhsuzluğunu göstermektedir (Fotoğraf 5). Tasarımlarında işleyen prosesleri, kumaşların aşınma ve yıpranmasını ve kullanım izlerini gözlemlemekte ve bu sayede hem yeni estetik, hem de yeni otantiklik elde etmektedir (Loshek, 2009:187). 


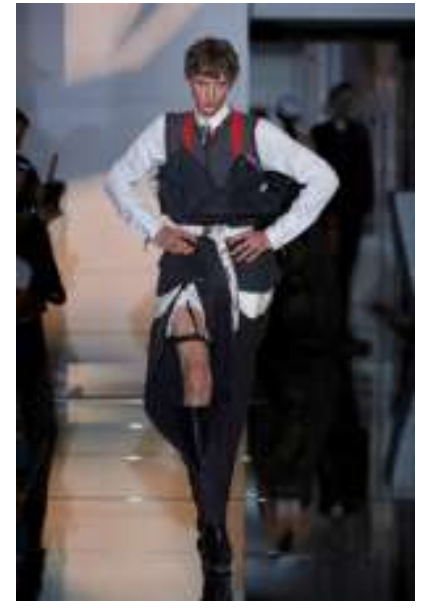

Fotoğraf 5: Margiela, Fall 2019 Couture

Günümüz modasına ilişkin yayınlarda “yırtık", "kötü görünümlü” veya "lekeli” giysiler "fakir modası" terminolojisiyle anılmaktadır. Rhodes (2010:14-15), fakir gibi giyinmenin, modanın uzunca bir süredir alttan desteklediği güzellik, şıklık ve çekicilik terimlerine sırt çeviren postmodern bir moda sisteminin ürünü olduğundan söz eder. Postmodernizm belirsizliğe değer verir ve zengin olan kıyafetleri meydana çıkartmak için çift-kodlamayı, ayrıca ironiyi kucaklar. Tüketiciler artık modernizm tarafindan şart koşulan taze ve orijinal idealleri talep etmemekteydiler: modadan delicesine arzuladığımız "yeni” kavramı artk eskisi kadar sabit değildi; aslında başka bir şeye dönüştürülmüsstü. Rhodes’a göre, Postmodernizm saf yenilik kavramını gölgede bırakmışı ve bunun yerine modada bulanıklık yaratan tarzlar için daha büyük bir genişlik üzerinde ve sonuç olarak da kusurluluğun kucaklanması üzerinde 1srarcı olmuştu.

Moda endüstrisinin geleneksel olarak faddizmi (bir moda akımına duyulan geçici düşkünlük/heves), ayrıcalıklı ve olağanüstü olmayı desteklediği gerçeğinin aksine, 1980’lerde başlayan fakir gibi giyinme modası, modanın direk olarak karşı özellikleriyle ilişkilendirilmiştir: Defolu, berbat olmuş ve düzgün olmayan kiyafetler giymek. Lüks moda olarak türetilen "fakir" giyinmek, doğası gereği hem güzellik hem de çirkinlik konseptlerinin göze çarpan bir birleşimidir. Deliklerin, lekelerin, yırtıkların ve sosyal gruplanı veya hedef kitleleri maskeleyen giysilerin görünüşleri, moda tasarımında üretken bir gerginlik sinyali vermektedir. Fakir gibi giyinmek bir yandan "yaratıcı yıkım"1n sürekli basit olan, "lezzetli" tasarımların ve insanların yüzsüzce lüks arayışının yüzünde dönüşebilir, bireyselleşen etkilerini somutlaştrırken, bir yandan da ilgi çekmek için gerçek fakirliğin sömürgeleştirilmesini ve nesneleştirilmesini temsil etmektedir (Rhodes, 2010:14-17-30).

Çağdaş moda tasarımlarıyla ilgili olarak, genellikle deliklerin, yırtıkların, bitirilmemiş elbise kenarlarının, yamaların ve geri dönüştürülmüş kıyafetlerin görünüşleri ve anlamları, lüks moda bağlamında düzanlamsal ve çağrımsal tasarım özelliklerinin de karışmasına öncülük etmektedir. Örneğin Levi's ve J. Crew gibi markalar tarafindan üretilen kıyafetler, kesildikten ve dikildikten sonra yeniden boyanmaları ve giyilebilir bir görünüş taklit edilebilmesi adına yıkanmaları için kimyasal bir sürece sokulmaktadırlar (akt. Rhodes,2010:122). Böylece, fakirlik estetiğini ifade ettiği söylenebilen bir giysi neredeyse her zaman yenidir fakat basitçe eskidir veya bozulmuş bir giysinin görüntüsüne sahiptir (Rhodes,2010:122).

İlginç biçimde Alexander McQueen da, yırtık görünümleri grotesk bir anlayışla ilişkili biçimde koleksiyonlarına aktarır. Koleksiyonlarındaki temel düşüncesi "groteskten yola çıkarak güzelliği yeniden, başka bir biçimde yaratmaktır. İtici (güzel) olduğu kadar çekici (çirkin) olan, iki karşıt duyguyu buluşturan groteskte güzellik bulduğunu söyleyen A. McQueen’in kimi tasarımları groteskin kanonlaşmış tanımlamalarına baştan sona uymaz, daha çok çiftil değerlerde şu ya da bu yan baskın çıkar": Highland Rape'de (Fotoğraf 6) yırtık giysiyi tarihi bir referansla şiddeti (kadına 
şiddeti), soykırımı (İngiltere'nin İskoçya'yı istila etmesi) yererek tasarımın anlatısı haline dönüştürür. The Hunger çirkin ve pis nesnelerin baskın çıktığı bir koleksiyonunda benzer biçimlere rastlanır. "Bir mankenin göğsünde görülen kurtlar, kan ve çamur lekeleri iğrençliğin doruk noktasıdır... Önce hayvanlaştırlan, sonra mekanik bir görünüm verilen mankenler aracilığılla A. McQueen yeni toplum düzeninde değerlerin yitimine vurgu yapar. Bedenin hasar görmesi, yara bere içindeki görünümü, yırtık giysiler modern toplumun insanı hiçleyici tutumunu simgeler"' (Aktulum, 2019).

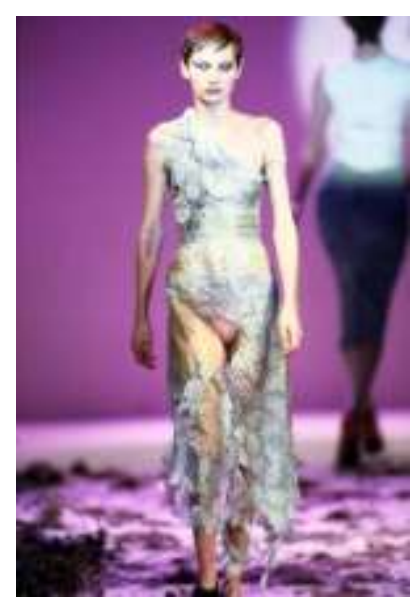

Fotoğraf 6: Alexander McQueen, Highland Rape Dress, Autumn/Winter 1995-96

Bir bakıma giysi yüzeyindeki "yırtık" görünümler modern toplumlarda "yoksulluk" izleğinin idealize edilmiş güzellik anlayışına dönüşmesine de tanıklık ederek giysilerin psikolojik açıdan sorgulanmasını da değerli kılar. Bu söz konusu anlayış bize Lisa Jansen'ın, kostüm tasarımcısı olarak bir sinema sahnesinde hüzünlü aşk şarkıları söyleyen oyuncu üzerinde yarattığ1 etkiyi söze döktüğü ve cinsel cazibe konusunda altın kural olarak önerdiği şu sözlerine yaslanır: “...Her şeyi göstermeyin... İlle de teninizin çok geniş yüzeylerini sergilemeniz gerekmez. Vücudunuzla saklambaç oynamanız daha yerinde olur" (akt. Davis, 1997:103).

Gerçekten de vücudun belirli bir bölgesinin görünürlülüğ̈nü sağlama, estetik bir beğeni yaratma ve hoşa gitme fikrini destekler. Bu beğeni vücudun sınırlı alanlarının açığa çıkarılarak güzelliğin başka biçimde takdir görmesini sağlar. Çıplaklık burada hiç de cezp edici bir durum değildir. Çünkü açığa çıkan her şey gizemini kaybeder ve sıradanlaşır. Tenin gizli kalmış yanlarının gizemini arttırarak merak uyandırmak veya bedene ait bir parçayı sınırlı çerçevede göstermek bedenin ulaşılmazlığını attırarak görünmeyeni daha da çekici hale getirir.

\section{Sonuç}

Giysilerin açık veya örtük biçimlerde kültürel imgelere ve düşüncelere ilişkin çeşitli mesajlar içermeleri, bu mesajların ise alıcı tarafindan doğru şekilde anlamlandırıldığı sürece amacına hizmet edeceği bilinen bir gerçektir. Giysilere görsel göndergelerle kazandırılan bu anlam kurgusunun, zamansal ve uzamsal açılardan farklı şekillerde belirmesi, yırtığın birçok kültürde bambaşka anlamlara geleceği gerçeğine vurgu yapar.

Yırtık olgusu başlı başına yüzeyin kesilmesi veya yıpratılmasıyla oluşan bir deformasyon işlemi iken, kimi zaman görünenin aksine bambaşka söylemlere karşllık gelerek birincil ve temel işlevinden daha öte birçok anlayışla ilişkilendirilmiştir. Bir bakıma insanlık tarihinden postmodern süreçte giysilerde var olan "yırtk" biçimlerin yokluktan soyluluğa; soyluluktan asiliğe; asilikten zenginliğe geçiş yapan çok anlamlı bir yapısı bulunmaktadır. 
Yırtık giysi biçimi, modanın bir parçası halini almadan önce geleneksel toplumlarda kültürel, toplumsal ve ekonomik göndermelerle ilişkili olarak (köleci ve tarıma dayalı), yoksunluğun ve yoksulluğun bir göstergesi halini aldığı görülmüştür. O dönemde yüzeylere çeşitli kumaş parçalarıyla kapatılarak yama yapılması, yırtık biçimlere referans sağlayan bir görünümdür. Ardından "Slashing" adı verilen bir stile dönüşen "yırtık görünüm" savaşın izlerinin soyluluk izlerine dönülmesine tanıklık eder. Askeri üniformalar üzerindeki yırtıkların kapatılması amacıyla yapılan doğaçlama biçim, toplumsal beğeni sonucu estetik biçimlere sokularak saray giysilerinde güç ve iktidarın temsilini imler.

Birtakım düşünsel referansların sosyoloji ve psikolojik açıdan gösterge aracı konumunda olduğu yırtık biçimler, alt kültür gruplarının da en temel stillerinden biri olmuştur. Genel olarak standart kurallara karşı isyan ve saldırganlık barındıran tepkisel tutumlarını kıyafetlerindeki yırtık biçimleriyle ifade ettikleri görülmüştür.

Yırtık görünümünün felsefik sorgulamayla birleştiği nokta, dekonstrüktivizm kavramının moda tasarımıyla kesiştiği noktada doğmaktadır. Mutlak doğru olmaksızın farklı doğruların da olabileceği gerçeğine dayanan bu kavram, giysi tasarımında doğru bilinen yanları ters yüz etmek ve yap1 bozumuna uğratmakla belirginleşir. Kısaca yüzeydeki yırtık görünümüm de yapıbozumun görünür bir niteliği olarak karşımıza çıktığını belirtmek mümkündür.

Postmodernizmin bulanıklaştırdığı estetik biçimler yırtı görünümlerin anlamını muğlaklaştırmasıyla ifade kazanmaktadır. Zenginlik ve fakirliğin yer değiştirdiği yeni stiller, yeni olmanın ötesinde geçmişe bir gönderme yaparak yoksulluk estetiği kazanmaktadır.

\section{Kaynakça}

Aktulum, K. (2019). Üstgiysisellik ve Grotesk. Kubilay Aktulum'a ait 2018-2019 Bahar Yaryylı yayımlanmamış ders notları (76 sayfa, teksir). Hacettepe Üniversitesi Edebiyat Fakültesi Fransız Dili ve Edebiyatı Bölümü, Ankara.

Ambrose, G., Harris, P. (2012). Görsel Moda Tasarımı Sözlüğü. Literatür Yayınları, İstanbul.

Baker, H. A., Baker P.C. (1985). Patches: Quilts and Community in Alice Walker's "Everyday Use", The Southern Review (Summer).

Barnard, M. (2002). Fashion as Communication, Second edition, Routledge, London and New York.

Bilal, M.(2018). Divanü Lügat-İt-Türk’e Göre Türklerde Giyim Kuşam Kültürü, Türk \& İslam Dünyas1 Sosyal Araştırmalar Dergisi, Yı1: 5, Sayı: 19, Aralık.

Bursalıgil, G. (2009) Antropolojik Açıdan Giyim Kültürü. Mimar Sinan Güzel Sanatlar Üniversitesi

Sosyal Bilimler Enstitüsü Tekstil ve Moda Tasarımı Anasanat Dalı Tekstil ve Moda Tasarımı Programı,

Yayımlanmamış Yüksek Lisans Tezi, İstanbul.

Cochrane, L. (2014). Zoo jeans: would you wear denim custom ripped by lions and tigers?, erişim: https://www.theguardian.com/fashion/shortcuts/2014/jul/08/zoo-jeans-custom-rippedlions-tigers, (Erişim Tarihi: 2 Mayıs 2019).

Crane, D. (2003). Moda ve Gündemleri, Ayrıntı Yayınları, İstanbul.

Çileroğlu, B., Balcı, M. (2018). Dekonstrüksiyon Kavramsalında Moda Tasarımı, Uluslararası Kültürel ve Sosyal Araştırmalar Dergisi, Cilt: 4 (1).

Davis, F. (1997). Moda, Kültür ve Kimlik, çev. Özden Arıkan, Yapı Kredi Kültür Sanat Yayıncilık, İstanbul.

Diakov, V., Kovalev, V. (2014). İlkçă̆ Tarihi Cilt I Ortadoğu, Uzakdoğu, Eski Yunan, Çev. Özdemir İnce, Yordam Yayınevi, İstanbul.

Ercivan, G., Meydan C. (2007). Modanın Dili, Yedi Dergisi, Say1: 1, http://www.mulkiyedergi.org/yedi/article/view/5000087184/5000081057 (Erişim Tarihi: 5 Mayis 2019).

Erol, D. (2013). 1900 Başlarından Günümüze Değişen Müzik ve Bu Müziğin Halk Gurupları Giyimine Etkisi, Beykent Üniversitesi Sosyal Bilimler Enstitüsü Tekstil ve Moda Tasarımı Anasanat Dalı Tekstil ve Moda Tasarımı Sanat Dalı, Yayımlanmamış Yüksek Lisans Tezi, İstanbul. 
Evecen, A. (2019). Giysilerdeki yırtk görünümlerin kimi anlamları üzerine yaklaşımlar. Journal of Human Sciences, 16(4), 916-930. doi:10.14687/jhs.v16i4.5804

Fidan, S. (2011). Türk Kültüründe Askeri Giyim-Kuşam ve Asker Modas1, Milli Folklor Dergisi, Say1 92. Fiske, J. (1999). Popüler Kültürü Anlamak, çev. Süleyman İrvan, Bilim ve Sanat Yayınları, Ankara.

14) Fogg, M. (2014). Modanın Tüm Öyküsü, Hayalperest Yayınevi, İstanbul.

Holmes, S. (2014). Now You Can Get Your Jeans Custom Ripped By Tigers, https://www.elle.com/fashion/news/a19432/now-you-can-get-your-jeans-custom-ripped-bytigers/ (Erişim Tarihi: 2 Mayıs 2019).

İşbilen, A. (2011). Modada Anarşizm, Phoenix, Ankara.

Koç, F., Koca, E. (2015). Kütahya'nın Entarili Geleneksel Kadın Giysilerinin Göstergebilimsel Çözümlemesi, Milli Folklor Dergisi, Yı1 27, Say1 106.

Kollektif (2013). Moda, Geçmişten Günümüze Giyim Kuşam ve Stil

Rehberi, , Çev. Duygu Özen, Kaknüs Yayıncllı, İstanbul.

Krales, A. (2017). A History Lesson On... Rei Kawakubo \& How She Challenged Western Fashion https:/ / bythecreativedepartment.wordpress.com/2017/05/02/a-history-lesson-in-reikawakubo-how-she-challenged-western-fashion/ (Erişim Tarihi: 2 Temmuz 2019)

Loschek, I. (2009). When Clothes Become Fashion,: Berg Publishers, New York.

Olson, K. (2017). Masculinity and Dress in Roman Antiquity, Oxon, Routledge, New York.

Özhan, S. (2018). Saçaklama Tekniği ve Pazen Kumaşa Uygulanması, Kalemişi-Türk Sanatları Dergisi, Cilt 6, Sayı:12.

Pendergast, S. ve T. Pendergast (2004). Fashion, Costume and Culture, Volume: 5, The Gale Group, Farmington Hills.

Püsküllüoğlu, A. (1999). Türkçe Sözlük, Doğan Kitapçllı, İstanbul.

Rhodes K. L. (2010). An Apparent Ugliness: Fashion and Dressing Poor, School of Architecture and Design Rmit University, Master of arts, https://researchbank.rmit.edu.au/eserv/rmit:12001/Rhodes.pdf, (Erişim Tarihi: 2 Temmuz 2019)

Rutli, E. E. (2016). Derrida’nın Yapısökümü, Temaşa Erciyes Üniversitesi Felsefe Bölümü Dergisi, Say1: 5 .

Saydam, O. (2009). Yazında “Dekonstrüksiyon” Kavramı. Frankofoni Dergisi, 21, Ankara.

Taschek, K. (2009). The Civil War, Infobase Publishing.

Tortora, P. G., K. Eubank, (2006). Survey of Historic Costume, 14. Bask1, Fairchild Publications, New York.

Warne, R. L. (2000). Costume, Dorling Kindersley, Incorporated, New York.

Volpintesta, L. (2014). The Language of Fashion Design, Rockport Publishers, America.

Yanık, H. (2016). Yapısöküm Üzerine Birkaç Not, Abant Kültürel Araştırmalar Dergisi (AKAR), Cilt 1, Say1 2.

Yilmaz, S. (2010). Giyim Kuşam Terimleri İngilizce-Türkçe, Dragoman, https://docplayer.biz.tr/461372-Giyim-kusam-terimleri-ingilizce-turkce.html, (Erişim Tarihi: 5 Haziran 2019)

Fotoğraf 1: Slashing Tarzı Giysi Stiline Bir Örnek, Henry VIII, King of England, 1540. https://www.learner.org/courses/globalart/work/268/index.html, (Erişim Tarihi: 13 Haziran 2019).

Fotoğraf 2: Punk Tarzı Giysi Stiline Bir Örnek, REX USA / Nils Jorgensen Londra, 1983. https://www.buzzfeed.com/maceyjforonda/19-filthy-furious-vintage-photos-of-earlypunk?utm_term=.markXGrr, (Erişim Tarihi: 16 Haziran 2019).

Fotoğraf 3: Zoo Jeans, http://zoo-jeans.com/, (Erişim Tarihi: 16 Haziran 2019).

Fotoğraf 4: Rei Kawakubo/Comme des Garçons, 1982, https://collections.vam.ac.uk/item/O73390/jumper-kawakubo-rei/, (Erişim Tarihi: 16 Haziran 2019).

Fotoğraf 5: Margiela, Fall 2019 Couture, https://www.vogue.com/fashion-shows/fall-2019couture/maison-martin-margiela/slideshow/collection\#7, (Erişim Tarihi: 19 Haziran 2019). Fotoğraf 6: Alexander McQueen, Highland Rape Dress, Autumn/Winter 1995-96, https://blog.metmuseum.org/alexandermcqueen/dress-highland-rape/(Erişim Tarihi: 19 Haziran 2019). 


\section{Extended English Summary}

Outlooks of ripped surfaces related to the garments, bear witness to a lot of styles that have different meanings. Several outlooks represent poverty at first view referring to its real meaning, but in time, it is unfolded that these outlooks are a mean of expression, startlingly, of abundance. While the traces of these compeller living conditions wrap itself up in weariness, it takes on a polyphonic meaning that reaches from deprivation to nobility and rebelliousness.

In this research, lexical changes on ripped surfaces are inquired by way of garment samples that are going to become apparent and the justifications of why the ripped shapes that are away from aesthetic concern at the beginning, turned into a style that evokes the fashion-loop, is clarified. In this context, the transformation of the ripped outlooks that starts from the dressing phenomenon and also notions and existence of class societies and reaches to the postmodern societies, from poverty to quite different meanings constitutes the extent of the study. When ripped outlooks of the garments gain a meaning related to a lot of social, cultural, economic, psychologic and/or geographic features, it enables this style to move beyond a "visual" value.

The research method of this study which is done within the scope of qualitative researches is document analysis and descriptive research. It is benefitted from the documentary scanning method as a technique of data collection. Data is procured by scanning publishings like native and foreign books, magazines and theses belong to the archives of the libraries of the universities and scientific and visual publishings reached via the internet. The study is exhibited relating to the five basic concepts that are revealed as a consequence of the researches devoted to shapes of ripped garments. The first of these concepts is the poverty path. It is seen that, in the beginning, ripped outlooks have shown up relating to the natural reactions. As follows, garments that have ripped outlooks were used by class societies as a consequence of the garment's becoming old because of the working conditions. Ripped shapes that are formed on the garments of the slaves because of the heavy living conditions, transformed into a mark of indication with the patches that have been used on garments. Moreover, it became a symbol of weariness on garment surfaces as a result of daily and compeller living conditions on agriculture-based traditional societies. It is seen that during past eras garments that are ripped and patched because of the workforce, used by traditional, in a way, agricultural societies. Subsequently, ripped outlooks were associated with the indicator of "nobility". Garments of the soldiers that were ripped as a result of harsh conditions of the war, were welcomed with admiration and bore witnesses to ripped garments' turning into a new style that was named by nobles as the "slashing" which makes a garment's interior surface seen from outside in consequence of the tears on the garments outside. Interestingly, contrary to the belief of past eras, ripped garments, who are a symbol of poverty, are started to being used with new shapes that are created by palace cuttings especially on 16 . century. The symbolic power of the "government and nobility" on garments have been discerned here.

Another meaning of the ripped outlook appeared on the garments of sub-culture groups that had their own attitudes and actions against social norms. Every stylistic element that ruins their outlook fed by their ideological opinions, provided them a new style for their garments and accessories. Jeans that they used very often, made ripped outlooks turn into a "rebellion" path, visible.

It is seen that deconstructivism shape that is based on "deconstruction" philosophy, which splits and dismantles various constructions and sensibly transforms them, corresponds to the styles which ruin aesthetic order and make them visible on garment designs too. From a technical aspect, the impressions of "unfinished" and "far from aesthetic" are given to the garments with the help of torn, ripped, faded and lopsided shapes.

The designs on which the sense of beauty is ambiguated and transferred to the new styles inspired by the old styles are being accepted as current, and the irony behind this acceptance is associated with the way of postmodern process' being transferred to the fashion styles. Also, designs related to the utilization of nonhomogenous pieces belong to the past or modern-days together, creates a polyphonic structure. As a consequence of this, it is seen on a lot of designs devised to indicate usage of several styles together, that attitude of postmodern outlook which creates ambiguity by wrapping itself up in a poor outlook is a reference to the ripped styles that serve to this outlook. 